\title{
PRODUCTIVE AND REPRODUCTIVE CHARACTERISTICS OF HOLSTEIN COWS RASIED UNDER INTENSIVE FARMING SYSTEM IN EGYPT
}

\author{
S. Abou-Bakr ${ }^{1}$,H.O.A. Alhammad ${ }^{2}$, R.R. Sadek ${ }^{1}$ and A.A. Nigm ${ }^{1}$ \\ 1- Department of Animal Production, Faculty of Agriculture, University of Cairo, \\ Giza, Egypt, 2-Department of Animal Production, Faculty of Agriculture, Allepo \\ University, Syria
}

\section{SUMMARY}

A total of 4382 lactation records for 1868 Holstein cows sired by 182 bulls in a herd belongs to The Modern Agricultural Development Company (Dina). The data were analyzed using SAS (1998) and DF-REML (Meyer, 1998) for estimating the phenotypic and genetic parameters of some productive and reproductive traits.

Means of total milk yield (TMY), 305-day milk yield (305-dMY), lactation period (LP), annualized milk yield (AMY), dry period (DP), days open (DO) and calving interval (CI) were $13172 \mathrm{~kg}, 10847 \mathrm{~kg}, 370$ day, $10899 \mathrm{~kg}, 63.47$ day, 154 day and 430 day, respectively.

All the studied traits, except AMY, were significantly affected by parity of the cow. Also, year of calving showed a significant effect on all traits. Season of calving showed no significant effect on all traits except TMY and DP.

Estimates of heritability ranged between 0.0003 for DP and CI to 0.13 for 305dMY. All estimates of the phenotypic and genetic correlation coefficients among these traits were positive. The results indicated that Holstein cattle in Egypt could produce high amount of milk if kept under reasonable management standards.

Keywords: Milk production, reproduction, heritability, Holstein, commercial farms, Egypt

\section{INTRODUCTION}

Imported standard dairy cows are known to yield large amount of milk as compared with native cows in developing countries. Imported breeds, however, are less adapted to local environmental. They need close attention and high standard of management. Therefore, they are usually kept in commercial farms belong to intensive farming systems.

Milk production is a complex character governed by both heredity and environment (Sahoo et al., 2003). Mostageer et al. (1987) reported that in absence of improved feeding, management, veterinary services, local environment would reject the high yielding dairy cows.

Annualized milk yield is an index, which reflects the intensity of lactation and combines milk yield and reproductive efficiency of a dairy cow. Producing more milk annually is a primary measure of efficiency because maximum production of

Issued by The Egyptian Society of Animal Production 
dairy cows has typically occurred with optimal management conditions (Kellogg et al., 2001).

Days open has been studied by several investigators because of its economical importance associated with the reproductive efficiency and fertility in dairy cattle. It is important in determining calving interval and influencing milk production (Ali et al., 2003).

The objective of the present study was to estimate the phenotypic and genetic parameters of some productive and reproductive traits of the Holstein cattle maintained under commercial dairy farming system in Egypt.

\section{MATERIALS AND METHODS}

This study was carried out on a Holstein herd belonging to the Modern Agricultural Development Company (Dina), located eighty kilometers north of Cairo. The animals of the original herd were purchased over the years 1987 to 1996 . They were selected from US Holsteins raised at and adaptable to similar weather conditions in Egypt.

The animals were kept under open sheds all the year round. Sheds were supported with a cool spraying system to be used in hot months. The animals were fed total mixed ration (TMR) all over the year. In order to preserve the genetic properties of the cows and heifers in the study, artificial insemination was practiced using frozen semen from the best 100 total predicted index (TPI) USA and Canadian bulls.

The data consisted of two sets of lactation records; 4382 records of productive traits and 2763 records of days open, calving interval and annualized milk yield. The records covered the period from 1996 to 2003.

The productive traits studied were total milk yield (TMY, $\mathrm{kg}$ ), 305day milk yield (305-dMY, Kg), the milk produced by the cow adjusted for 305 day and mature equivalent. Lactation period (LP, day), annualized milk yield (AMY, kg equals TMY divided by calving interval, in days multiplied by 365), dry period (DP, day). The reproductive traits were calving interval (CI, day) and days open (DO, day).

Analysis of variance and estimation of fixed effects were calculated by using the General Linear Model (GLM) procedure of SAS (1998). Heritability, repeatability, genetic and phenotypic correlations were estimated using the Derivative-Free Restricted Maximum Likelihood (DF-REML) procedure (Meyer, 1998). The following statistical model was used as:

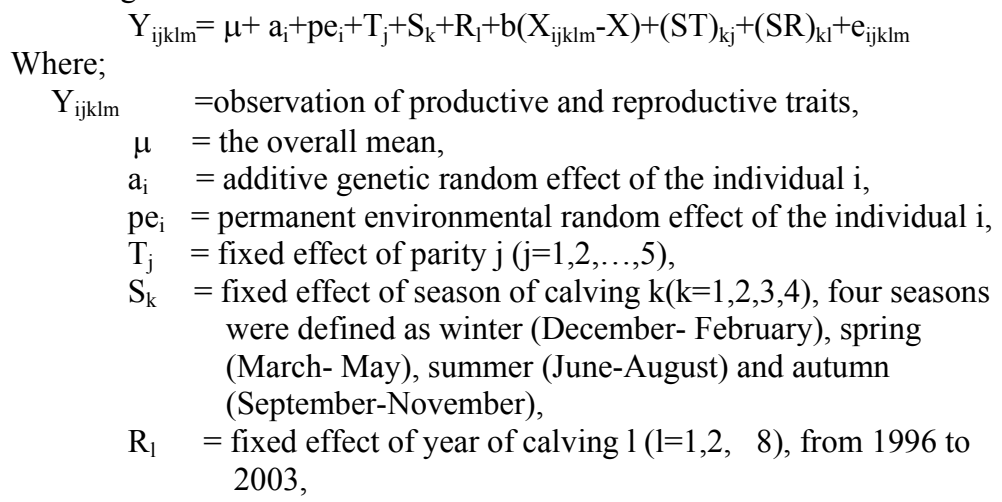


b = the linear regression coefficient of the studied trait on age at calving,

$(\mathrm{ST})_{\mathrm{kj}}=$ the interaction between season of calving and parity,

$(\mathrm{SR})_{\mathrm{kl}}=$ the interaction between season and year of calving, and

$\mathrm{e}_{\mathrm{ijklm}}=$ error term.

\section{RESULTS AND DISCUSSION}

Table 1 shows means, standard deviations (SD) and coefficients of variation (CV) of productive and reproductive traits of Holstein cows maintained at commercial farms. Coefficients of variation for productive traits were mostly reasonable and ranged from $20 \%$ for 305 -dMY to almost double that figure (39\%) for DP. However, it reached $57 \%$ in case of DO. The mean of 305-d MY exceeded 10 thousands $\mathrm{kg}$ which is quite comparable to the average production of the breed in temperate areas. This may refer to successful management of exotic standard breeds in commercial farms in Egypt. Annualized milk yield was very close to 305-dMY, the finding which refer to tendency of the breed for regular calving. This is supported by the estimates obtained for DO and calving interval (154 and 430 days, respectively).

Table 1. Means, standard deviations (SD) and coefficients of variation (CV) of productive and reproductive traits in Holstein cows maintained at a commercial farm

\begin{tabular}{lccc}
\hline Trait & Mean & SD & CV \\
\hline TMY, kg & 13172 & 4261 & 32 \\
305-dMY, kg & 10847 & 2206 & 20 \\
LP, day & 370 & 87 & 24 \\
AMY, kg & 10899 & 2458 & 23 \\
DP, day & 63.4 & 25 & 39 \\
DO, day & 154 & 88 & 57 \\
CI, day & 430 & 92 & 21 \\
\hline
\end{tabular}

The estimate of DO is close to the 152day reported by Mokhtar et al. (1993) on Holstein cows. But it was shorter than the 229 and 220 day scored on Holstein by Abou-bakr et al. (2000) and Mousa et al. (2001), respectively. While it was nearly the same 155 day reported by Oseni et al. (2003) on Holstein cows in U.S.A. ElKeraby and Aboul-Ela (1982) stated that the longer DO in cows may be caused by several factors, i.e. level of milk production, housing, silent heat, frequency and timing of oestrus detection, and season of calving. Also, Abdel Glil (1996) reported that the poor management leads to high variation in DO. However, in commercial farms the management policies might play the most important role in such variation. Ahmed et al. (2002) working on Holstein raised in Egypt, found that high productive cows scored longer days open and consequently prolonging the calving interval. They added that those cows are more profitable than those having regular calving interval of 12-13 months. 
Table 2. Level of significance $(P>)$ of factors affecting total milk yield (TMY), 305-day milk yield (305-dMY), lactation period (LP) and dry period (DP)for Holstein cows maintained at a commercial farm

\begin{tabular}{lccccc}
\hline \multirow{2}{*}{$\begin{array}{l}\text { Source of } \\
\text { Variation }\end{array}$} & d.f & \multicolumn{4}{c}{ P< } \\
\cline { 3 - 6 } & & TMY & 305-dMY & LP & DP \\
\hline Parity & 4 & 0.0024 & 0.0116 & 0.0001 & 0.0404 \\
Year of calving & 7 & 0.0001 & 0.0001 & 0.0001 & 0.0019 \\
Season of calving & 3 & 0.9080 & 0.0001 & 0.0001 & 0.4536 \\
Age at calving & 1 & 0.0039 & 0.0001 & 0.0001 & 0.1719 \\
Season x year & 21 & 0.001 & 0.0001 & 0.0001 & 0.0226 \\
Season x parity & 12 & 0.0039 & 0.0004 & 0.2344 & 0.2458 \\
\hline
\end{tabular}

Table 3. Level of significance of factors affecting annualized milk yield (AMY), days open (DO) and calving interval (CI) for Holstein cows maintained at commercial farms

\begin{tabular}{lcccc}
\hline Source of & d.f & & $\mathbf{P}<$ & \\
\cline { 3 - 5 } Variation & & AMY & DO & CI \\
\hline Parity & 3 & 0.9848 & 0.0001 & 0.0001 \\
Year of calving & 6 & 0.0001 & 0.0001 & 0.0001 \\
Season of calving & 3 & 0.0002 & 0.0001 & 0.0001 \\
Age at calving & 1 & 0.0003 & 0.0001 & 0.0001 \\
Season x year & 18 & 0.0243 & 0.0185 & 0.0025 \\
Season x parity & 9 & 0.0011 & 0.1293 & 0.3324 \\
\hline
\end{tabular}

Heritability estimates $\left(\mathrm{h}^{2}\right)$ for productive and reproductive traits are shown in table (4). The $\mathrm{h}^{2}$ estimates for total milk yield was 0.06 . This estimate is less than that obtained by Abou-Bakr et al. $(0.31,1996)$ and Abdel-Salam et al. $(0.09,2001)$. The differences between heritability estimates of the same trait in different studies are probably due to the available number of records used in estimation, the correction of data for non-genetic factors, the method of estimation, and the genetic constitution of the breed.

The estimates of $\mathrm{h}^{2}$ for 305 day milk yield (table 4) was 0.13 which is exactly the same value obtained by Atil (2000) who analyzed another set of data of Holstein in the same farm. The higher estimate of $h^{2}$ of 305-dMY as compared with that of TMY could be explained by that using records of 305-dMY (standardized records) reduced the environmental variance and consequently increase the estimate of $h^{2}$.

The lactation period had an estimate of heritability of 0.03 , which is close to the lower limit of the corresponding estimates obtained for Holstein in Egypt. This estimate is less than obtained by El-Arian et al. $(0.07,2003)$ and Abdel-Salam et al. $(0.12,2001)$. Low estimates of heritability for lactation period may be due to the large contribution of non-genetic factors to the total variation of this trait (Shitta et al., 2002).

Few estimates of $h^{2}$ for annualized milk yield (AMY) were published. The present estimate was slightly higher than 0.04 reported by Abdel-Salam et al. (2001) on Holstein in Egypt. 
Table 4. Estimates of heritability $\left(h^{2}\right)$, standard errors (SE) and repeatability (t) of productive and reproductive traits in Holstein cows

\begin{tabular}{lccc}
\hline Trait & $\mathbf{h}^{\mathbf{2}}$ & $\mathbf{S E}$ & $\mathbf{t}$ \\
\hline TMY, kg & 0.059 & 0.030 & 0.48 \\
305-dMY, kg & 0.130 & 0.040 & 0.79 \\
LP, day & 0.030 & 0.020 & 0.62 \\
AMY, kg & 0.070 & 0.040 & 0.41 \\
DP, day & 0.0003 & 0.000 & 0.30 \\
DO, day & 0.014 & 0.025 & -- \\
CI, day & 0.0003 & 0.000 & -- \\
\hline
\end{tabular}

Also, the $\mathrm{h}^{2}$ estimate of dry period was almost zero which is in accordance with that reported by Atil (2000). This means that this trait is completely controlled by non-genetic factors.

The relatively low $\mathrm{h}^{2}$ estimates of the productive traits in this study reflects a small contribution of additive genetic variance. This indicates that improvement in such traits could be achieved mainly through improved feeding and management systems. Moreover, repeatability estimates (table 4) for the same traits refer to that the proportion of phenotypic variation due to the permanent environmental effects of the cow was high. These findings may be explained by severe selection in this herd to the extent that the experimented animals should be considered a selected group of the herd.

The present $h^{2}(0.014)$ for days open falls in the range of the published estimates in Egypt. While estimate for calving interval was almost zero.

Abded Glil (1996) and Shitta et al. (2002) reported that the low estimates of $h^{2}$ for days open and calving interval, indicate that a major part of variation in these traits were environmental and selection would not be effective in bringing out genetic improvement. Management improvement like detection of estrus, insemination technique, herd health programs and nutrition can therefore play an important role in improving reproductive performance at higher production (El-Arian et al., 2003). Therefore, genetic selection to improve reproductive efficiency would be meaningless and should depend mainly on managerial control.

All estimates of phenotypic and genetic correlations (table 5) among the productive traits were positive. Most of the genetic correlation coefficients were higher than their corresponding phenotypic correlation coefficients. This means that, there are negative environmental correlations among all the traits.

Table 5. Phenotypic correlations ( $r_{p}$ above the diagonal) and genetic correlations ( $r_{\mathrm{g}}$ below the diagonal) among productive traits in Holstein cows

\begin{tabular}{lcccc}
\hline Trait & TMY & 305-dMY & LP & DP \\
\hline TMY & & 0.08 & 0.29 & 0.32 \\
305-dMY & 0.20 & & 0.01 & 0.25 \\
LP & 0.50 & 0.24 & & 0.33 \\
DP & 0.48 & 0.32 & 0.52 & \\
\hline
\end{tabular}


Table 6. Phenotypic correlations ( $r_{p}$ above the diagonal) and genetic correlations ( $r_{g}$ below the diagonal) among days open (DO), calving interval (CI) and annualized milk yield (AMY) in Holstein cows

\begin{tabular}{lccc}
\hline Trait & DO & CI & AMY \\
\hline DO & & 0.53 & 0.48 \\
CI & 0.84 & & 0.50 \\
AMY & 0.82 & 0.82 & \\
\hline
\end{tabular}

All estimates of phenotypic and genetic correlations among DO, CI and AMY were high and positive (table 6). The results showed that AMY is important in determining DO and CI. Also, selection for higher AMY would be associated with prolongation of length of DO and CI.

\section{CONCLUSION}

Parity, season and year of calving had significant effects on most of the productive and reproductive traits studied. That emphasizes the importance of management in raising high yielding animals under harsh environments.

Low estimates of heritability obtained for most of the traits studied would be due to the severe selection of the cows when the herd was built up.

The increase in milk production was accompanied by longer periods of days open and calving interval. Further studies are needed to assess the economic feasibility of long calving interval, in commercial farms, for high yielding cows.

\section{REFERENCES}

Abdel Glil, M.F., 1996. Estimation of genetic parameters and trends for some milk traits in herd of Friesian cows in Egypt. Fac. Of Agric., Zagazig Univ., 21(10): 3479.

Abdel-Salam, S.A.M., U.M. El-Saied, S. Abou-Bakr and M.A. M. Ibrahim, 2001. Phenotypic and genetic parametters of milk production traits of a Holstein commercial herd in Egypt. Egypt.J.Anim.Prod., 38: 87.

Abou-Bakr, S., R.R. Sadek, M.K. Hamed, M.A.M. Ibrahim and A.S. AbdelAziz,1996. The use of milk records obtained by different recording schemes in sire evaluation of Holstein cattle in Egypt. Egypt. J.Anim.Prod., 33 : 39.

Abou-Bakr, S., U.M. El-Saied, and M.A.M. Ibrahim, 2000. Genetic and phenotypic parameters for milk yield, days open and number of services per conception of Holstein cows of a commercial herd in Egypt. Egypt. J.Anim. Prod., 37(1): 9.

Ahmed, A.M., A.K. El-Asheeri, M.A.M. Ibrahim and A.H.Barkawi.2002. Impact of milk yield on economics of Holstein herds under Egyptian conditions. Egypt. J. Anim. Prod., 39: 1.

Ali, A.K.A., A.M. Al-Seaf, M. A. Alshaikh, M.S. Alkriadees and A. Al-Haidary, 2003. Effect of non-genetic factors on lactation curve of Holstein Friesian cows in Saudi Arabia. J. King Saud Univ., 15: 115.

Atil, H., 2000. Genetic relationship between days open and days dry with milk yield in a herd of Holstein Friesian cattle. Archiv fur Tierzucht. Forschungsinstitut fur die Biologie landwirtschaftlicher Nutztiere, Dummerstorf, Germany.43: 583 (CAB Abstr). 
El-Arian, M.N., H.G. El-Awady and A.S. Khttab, 2003. Genetic analysis for some productive traits of Holstein Friesian cows in Egypt through MTDFREML program. Egypt. J. Anim. Prod., 40: 99.

El-Keraby, F. and M.B. Aboul-Ela. 1982. Study of some non-genetic factors affecting post partum and reproductive performance in Friesian cow. Tropical Animal Prod., 7: 307 (Cited by Kassab et al., 2001).

Kellogg, D.W., J.A. Pennington, Z.B. Johnson and R. Panivivat, 2001. Survey of management practices used for the highest producing DHI herds in the United States. J. Dairy Sci., 84: 120.

Meyer, K. 1998. DF-REML (Derivative- Free Restricted Maximum Likelihood) Package. Version 3.0, $6^{\text {th }}$ World Cong. Genetic Appl. Livest. Prod. Armidal, New Southwales, Australia.

Mokhtar, S., M.A. El-Alamy and A. Amin, 1993. Evaluation of productive and reproductive performance of some dairy cattle breeds in Egypt. Egypt. J.Anim.Prod., 30: 161.

Mostageer, A., M.A. Morsy, A.A. Nigm, and R.R. Sadek, 1987. The performance of some European cattle breeds in adverse environments. J. Anim. Breed. Genet. 104: 206.

Mousa, E.,U.M. El-Saied and M.A.M Ibrahim, 2001. Genetic analysis of number of services per conception and days open as continuous and binary traits using GIBBS sampling and REML in Holstein cows. Egypt. J.Anim.Prod.,38: 51.

Oseni, S.,I. Misztal, S. Tsuruta, and R. Rekaya. 2003. Seasonality of days open in US Holstein. J. Dairy Sci., 86: 3718.

Sahoo, NR., PN. Srivastava, SN. Sparmar, and PV. Apillai. 2003. Factors affecting production traits in Malvi cows. Indian. J. Anim. Sci., 73: 703.

SAS Procedures Guide, Version 6.12.1998. SAS Inst., Inc., Cary, NC.

Shitta, A.A., M.A. Tag El-Dien, and S.S. Awad, 2002. A study on production and reproduction traits of Friesian cattle in Egypt. J. Agric. Sci., Mansoura Univ., 27: 7281. 
الخصائص الإتتاجية والتناسلية للأبقار الهولثتين المرُباة تحت النظام المُكثف فى مصر

سامى أبو بكر1، حارث حماد²، ربيع رجب صادق1'، على عطية نجم1

1- قسم الإتتاج الحيوانى، كلية الزراعة، جامعة القاهرة، الجيزة، مصر2- قسم الإتاج الحيوانى، كلية الزيراعة، جامعة حلب، سورياج

أستخدم فى هذه الدراسة 4382 سجل إنتاج لبن لـ 1868 بقرة هولثنتين ملقحة بـ 182 طلوقة ، فئل في قطيع

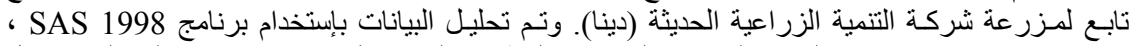

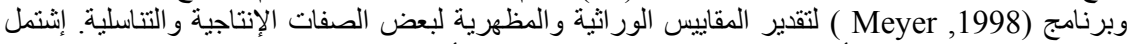

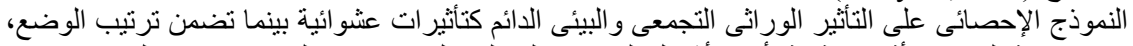

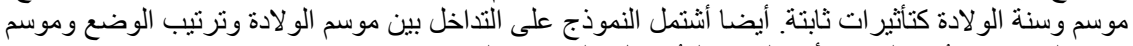

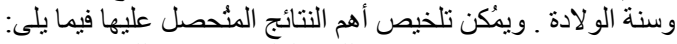

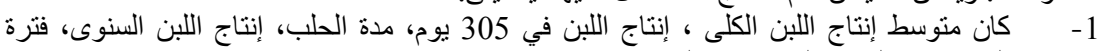

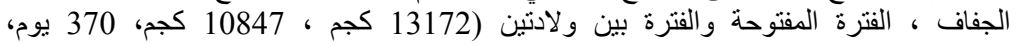

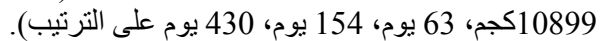

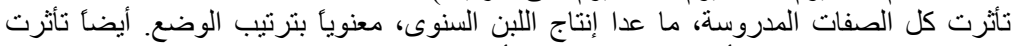

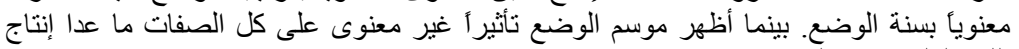

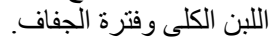

تراوحت قيم العمق الور اثىى من 0.0003 لصفة فترة الجفاف و الفترة بين و لادتين إلى 0.13 لصفة

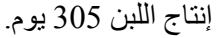
كُانت كل قيم معُامل الإرتباط المظهرى و الور اثى بين تلك الصفات موجبة.

تثنير النتائج إلي أن أبقار الهولثتين في مصر يمُكنها إنتاج كميات كبيرة من اللبن إذا تمت تربيتها تحت نظم رعاية جيدة. 